\title{
Use of Fish Silage Based Blended Protein Source for Replacement of Fish Meal in Thai-Pangas Diet
}

\author{
Makamguang Kamei ${ }^{1}$, Brundaban Sahu ${ }^{2}$, Sudhanshu Raman ${ }^{3 *}$, Soumendra Nanda ${ }^{2}$, \\ Dhariti Choudhury ${ }^{2}$ and M.S. Dorothy ${ }^{3}$ \\ ${ }^{1}$ Central Institute of Fisheries Education, Mumbai-400061, India \\ ${ }^{2}$ College of Fisheries (OUAT), Rangailunda, Berhampur-760007, India \\ ${ }^{3}$ National Fisheries Development Board, Hyderabad-pin code, India
}

*Corresponding author

\begin{tabular}{|c|c|}
\hline \multicolumn{2}{|r|}{ A B S T R A C T } \\
\hline & \multirow{5}{*}{$\begin{array}{l}\text { A study was carried out to assess the impact of replacement of fish meal by fish silage } \\
\text { based blended protein source in Thai-pangas (Pangasianodon hypophthalamus) diet. Five } \\
\text { isonitrogenous experimental diets with } 35 \% \text { crude protein level were formulated by } \\
\text { replacing fish meal at blended protein source consisting of one third each of fish silage, } \\
\text { groundnut oil cake and soya bean meal The growth performance of } P \text {. hypophthalmus after } \\
\text { feeding with different experimental diets was significantly different. After } 90 \text { days of } \\
\text { feeding trial the experimental diet with } 75 \% \text { of the fish meal content significantly) higher } \\
\text { growth rate of } 391.64 \% \text { than all other experimental diets. The, experimental diet } \\
\text { containing } 0 \% \text { fish meal and } 100 \% \text { blended protein source showed significantly lower } \\
\text { growth rate. The food conversion ratio (FCR) of the experimental diet } \mathrm{T}_{3} \text { was also } \\
\text { significantly better than all other diets. The better growth performance of experimental this } \\
\mathrm{T}_{3} \text { might be due to the better availability of digestible protein due to the enzymatic action } \\
\text { during the process of silage preparation. After considering all the factors analyzed in the } \\
\text { study it may be concluded that the cost effective diet for Thai pangus (P. hypophthalmus) } \\
\text { may be formulated by replacing } 75 \% \text { of the fish meal with blended protein source for } \\
\text { better performance in terms of growth of the fish. }\end{array}$} \\
\hline & \\
\hline Arti & \\
\hline & \\
\hline & \\
\hline
\end{tabular}

\section{Introduction}

Fish silage is an attractive alternative source to replace fish meal and produced from the whole fish or parts particularly the processing waste, to which acids, enzymes or lactic acidproducing bacteria are added, where the liquefaction of the mass is provoked by the action of inherent enzymes of the fish (FAO 2003).
Fish waste generated by processing and commercialization stations cause serious environmental hazards. A viable alternative would be to use the waste material in the manufacture of the fish silage, since it does not require high investments. The manufacturing of silage fish processing waste with an aim to utilize it as an aquaculture feed ingredient has been widely studied over the last few years. Many authors believe that, due 
to the similarity of this protein source with the raw material, especially amino acids, such as lysine, methionine, and cystine, silage has a high potential for use in aquaculture. Its low cost, especially when compared to fish meal is also attractive (Ferraz de Arruda 2004. Goddard and Perret 2005, Vidotti et al., 2003).

Fish silage a liquid product with about $80 \%$ water content there are limitations on the quantity of silage that can be added while manufacturing feed. The silage however can be blended with some low cost protein source; after which it can be used.

The stripped catfish, Thai-pangas (Pangasianodon hypophthalmus) is a widely cultured aquaculture species that is famous for its fast growth rate, hardy, consume different types of food and can survive in low water quality environment. Commercial culture of this fish species is fast gaining importance as a result, there is continuous increase in its production volume that has exceeded 150,000 MT (Phuong et al., 2005). The EU is currently the major market for Pangasius (especially from Vietnam, which is the largest producer). New markets such as Russia, the Middle East and some Asian countries have also demonstrated a growing demand for the fish (Josupeit, 2009b). However, the cost of production of Thai-pangas utilizing conventional fish feed is not matching well with the farm gate price of the fish. Therefore, reduction of cost of feed for Pangas is the need of the hour. It is in this context; the present study has been proposed to study on the use of fish silage based blended protein source for replacement of fish meal in Thaipangas.

\section{Materials and Methods}

The study was undertaken to evaluate the feasibility of fish silage based blended protein as a cheaper and alternative source to replace the fish meal in Thai pangus (Pangasianodon hypophthalmus) diet

\section{Experimental details}

Pangasianodon hypophthalmus (Thai-pangus) fingerlings were procured from a private fish farm of Chatrapur, Ganjam (Odisha). The stock was acclimatized in 6 FRP tanks of 2001 capacity under aerated conditions for 15 days. During the period of acclimatization, the fish were fed with ABIS floating fish feed at about 5 percentvof their body weight twice a day. The experiment was conducted by segregating and stocking of identical size fish with an average weight of $3.6 \pm 0.08$ g. Five isonitrogenous experimental diets with 32percentcrude protein level were formulated namely; $\mathrm{T}_{0}, \mathrm{~T}_{1}, \mathrm{~T}_{2}, \mathrm{~T}_{3}$ and $\mathrm{T}_{4}$. The diet $\mathrm{T}_{0}$ is the conventional fish meal based diet and served as the control diet. Other diets $\mathrm{T}_{1}, \mathrm{~T}_{2}$, $\mathrm{T}_{3}$ and $\mathrm{T}_{4}$ had fish silage based blended protein source replacing fish meal at 25, 50, 75 and 100percent, respectively. The blended protein source was prepared taking one third each of fish silage, groundnut oil cake and soya bean meal on dry weight basis (Table 1).

The quantity of individual ingredients required to formulate a $\mathrm{kg}$ of diet was worked out using Hardy's square method to balance protein levels. Energy level was balanced by adding oil. All the ingredients were pulverized in a hammer mill pulverizer (Kohinoor make) to get the fine powder of each (Table 1). Then, all the ingredients in required quantity except vitamin and mineral mixture were hand mixed to ensure homogenous mixing followed by addition of required quantity of boiled water and hand kneaded to form thick dough. The dough thus prepared was cooked in an autoclave for 15 minutes at 15 PSI pressure to sterilize the mixture and to remove antinutritional factors if any. The cooking also helped in gelatinization of starch content and improved the binding capacity of the feed for 
water stability. Dough was then cooled under room temperature. After proper cooling, required quantity of vitamin and mineral premix was added, mixed properly by hand kneading to prevent immobilization of vitamin and mineral premix.

The dough was then pelletized by using a hand pelletizer and oven dried for overnight at $75^{\circ} \mathrm{C}$ to in a hot air oven (MIC make).

Finally, the dried pellets were crumbled to approximate size and stored in air tight container before feeding to the experimental animals.

\section{Method of feeding}

Feeding was done at $4 \%$ of body weight initially and then the feeding was adjusted to the consumption so that there is almost nil feed is left. Daily ration was divided into two parts; one part was given at 09:00 hours and the other was given at 16:00 hours.

\section{Physico-chemical parameters of water}

Water quality of rearing water namely: temperature, $\mathrm{pH}$, DO, total alkalinity and ammonia nitrogen were recorded before and after water exchange during the experimental period following standard protocol (REF).

\section{Proximate composition of experimental diet}

The proximate composition of experimental diets was done by prescribed method (AOAC, 1998)

\section{Growth parameters}

The growth parameters of the Pangasianodon hypophthalmus were assessed by taking their body weight with respect to the feed given at an interval of 30 days. The feeding ration was also adjusted according to the weight gain by the fishes.

\section{Results and Discussion}

The experiment was conducted to evaluate the possibility of using silage prepared out of fish dressing waste as an alternative source of protein in the diet of Thai-Pangas ( $P$. hypophthalmus) and to find out its effectiveness and other possible consequences. The results of the research have been presented as tables and graph in this chapter with appropriate statistical analysis.

\section{Physico-chemical parameters of water}

Water temperature was recorded once in the early morning and again in the late afternoon once in a month.

\section{pH}

There was not much variation in $\mathrm{pH}$ values during the experimental period. The average $\mathrm{pH}$ value just before and after water exchange were recorded as $8.8 \pm 0.12$ and $8.2 \pm 0.22$, respectively in all the tanks.

\section{Temperature}

The average water temperatures of the experimental tanks in the morning and in the late afternoon were $26.8 \pm 0.18^{\circ} \mathrm{C}$ and $28.6 \pm$ $0.25^{\circ} \mathrm{C}$, respectively.

\section{Dissolved oxygen}

The average dissolved oxygen (DO) concentrations of the experimental tanks were recorded just before water exchange and after water exchange was $4.2 \pm 0.14$ and6.8 \pm $0.18 \mathrm{mg} / \mathrm{l}$, respectively.

\section{Total alkalinity}

The total alkalinity was $250 \pm 0.08$ and $298 \pm$ $0.13 \mathrm{ppm}$, respectively before and after water exchange during the experimental period of 90 days in all the tanks. 
Fig.1 Proximate composition of experimental diets (on wet weight basis)

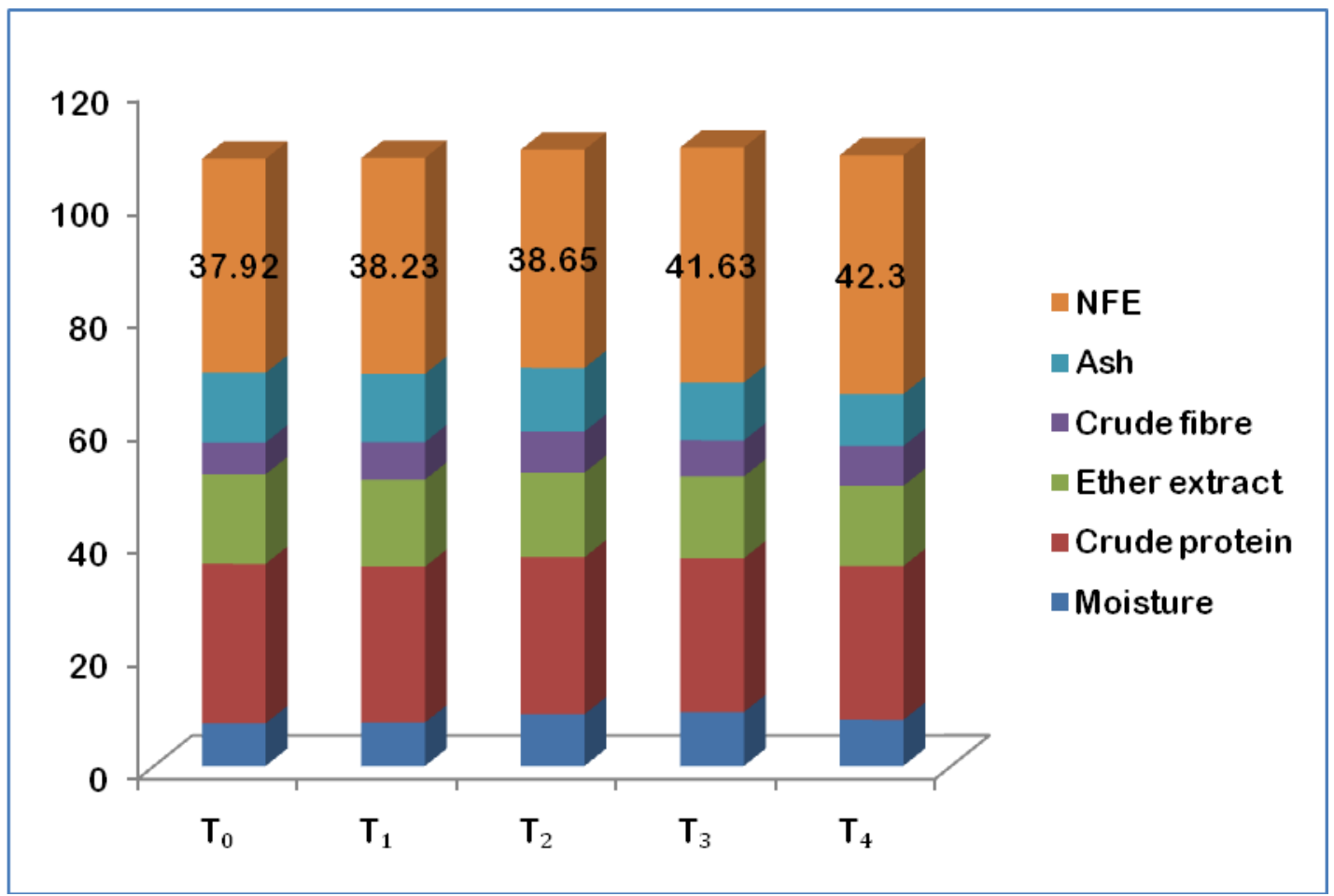

Fig.2 Proximate composition of experimental diets, $\mathrm{T}_{0}$ (on wet weight basis)

\section{$\operatorname{Diet} \mathbf{T}_{0}$}

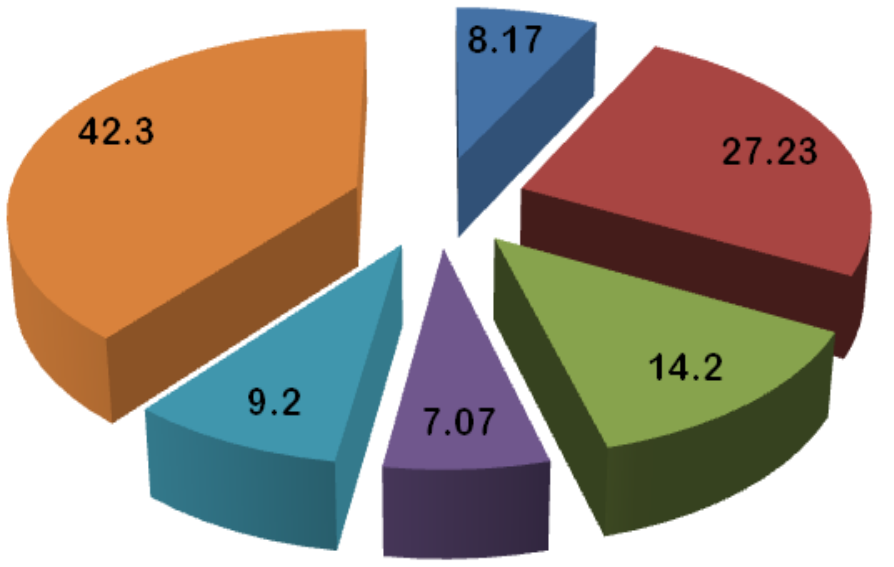

Moisture

Crude protein

Ether extract

- Crude fibre

Ash

NFE 
Fig.3 Proximate composition of experimental diets, $\mathrm{T}_{1}$ (on wet weight basis)
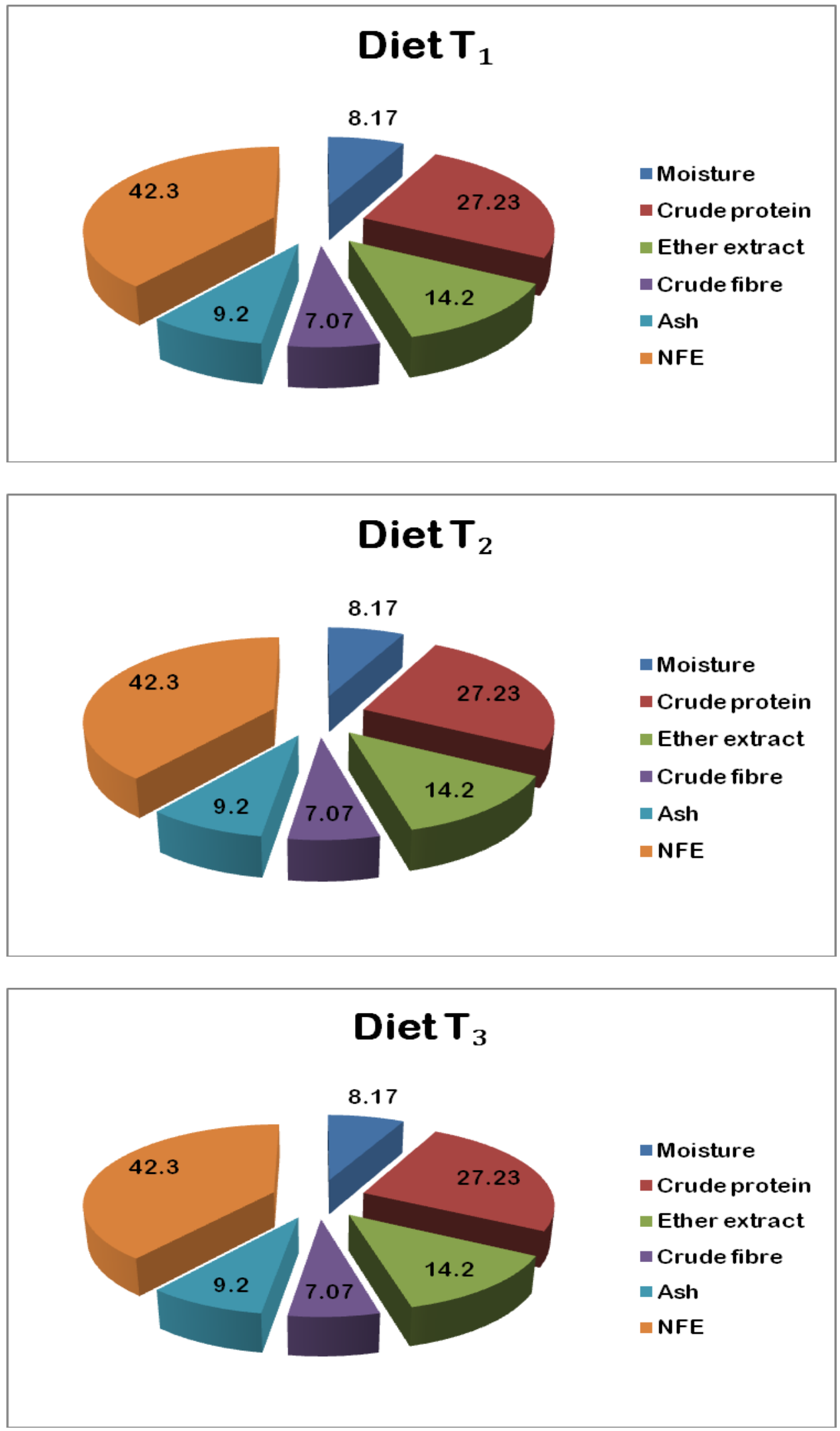

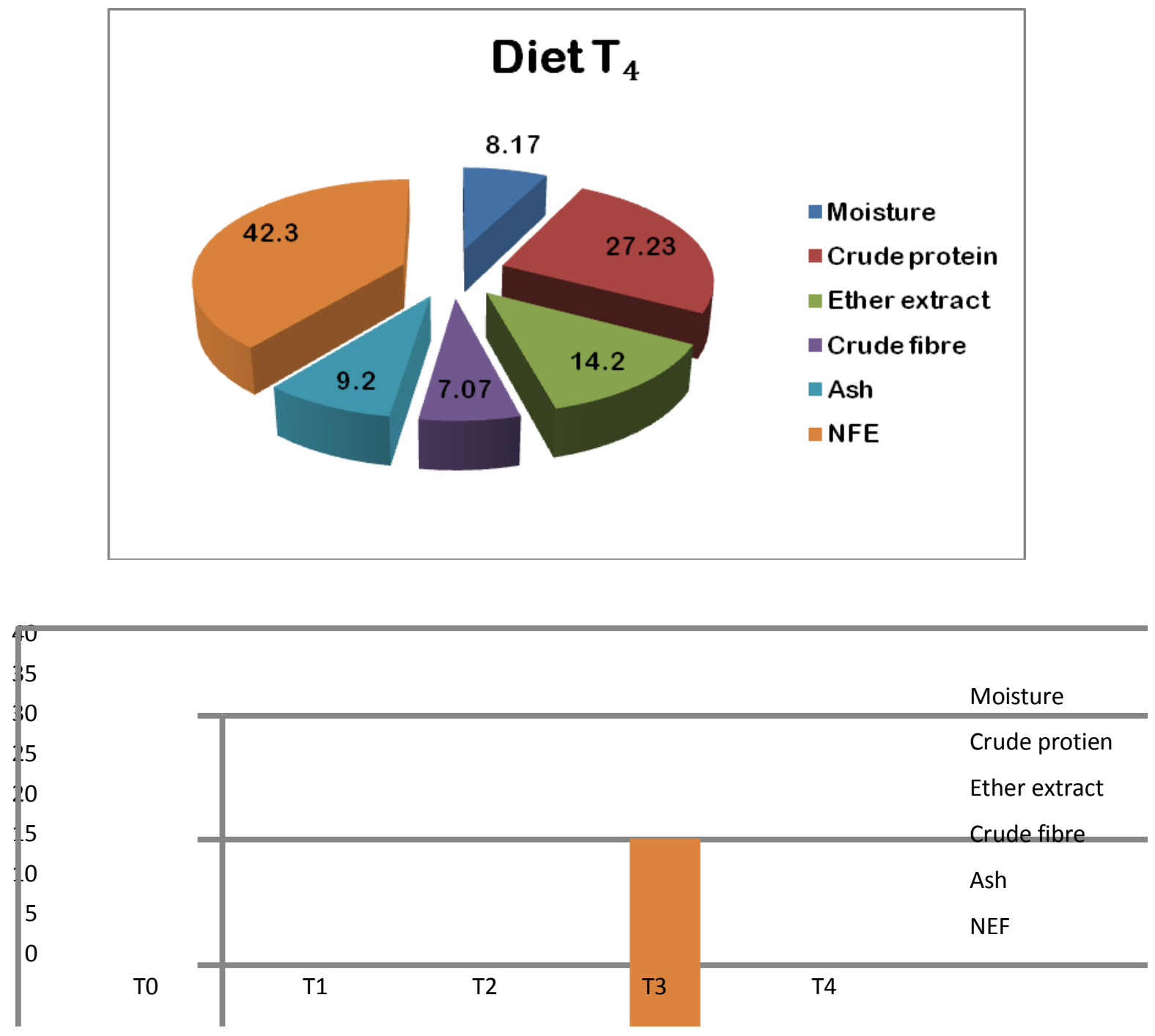

Table.1 Ingredient composition ( $\mathrm{g} / \mathrm{kg}$ dry matter basis) of experimental diets

\begin{tabular}{|l|}
\multicolumn{1}{|c|}{ Ingredients } \\
\hline Fish meal \\
\hline Blended protein source \\
\hline Groundnut oil cake \\
\hline Mustard oil cake \\
\hline Soya bean oil cake \\
\hline De-oiled rice bran \\
\hline Lipid (Fish oil : Sunflower Oil:: 1:1) \\
\hline Vitamin \& Mineral mixture * \\
\hline Corn Flour \\
\hline
\end{tabular}

\begin{tabular}{|c|c|c|c|c|}
\hline \multicolumn{5}{|c|}{ Experimental Diets } \\
\hline $\mathbf{T}_{\mathbf{0}}$ & $\mathbf{T}_{\mathbf{1}}$ & $\mathbf{T}_{\mathbf{2}}$ & $\mathbf{T}_{\mathbf{3}}$ & $\mathbf{T}_{\mathbf{4}}$ \\
\hline 360 & 270 & 180 & 90 & 0 \\
\hline 0 & 100 & 200 & 310 & 410 \\
\hline 90 & 90 & 90 & 70 & 70 \\
\hline 90 & 90 & 80 & 60 & 50 \\
\hline 60 & 60 & 70 & 90 & 90 \\
\hline 260 & 250 & 240 & 240 & 250 \\
\hline 80 & 80 & 80 & 80 & 80 \\
\hline 30 & 30 & 30 & 30 & 30 \\
\hline 30 & 30 & 30 & 30 & 20 \\
\hline
\end{tabular}


Int.J.Curr.Microbiol.App.Sci (2018) 7(10): 2949-2961

Table.2 Proximate composition of experimental diets

\begin{tabular}{|c|c|c|c|c|c|c|c|c|c|c|}
\hline \multirow{2}{*}{$\begin{array}{c}\text { Experimental } \\
\text { Diet }\end{array}$} & \multirow[t]{2}{*}{ Moisture } & \multirow{2}{*}{$\begin{array}{c}\text { Total } \\
\text { dry } \\
\text { matter }\end{array}$} & \multicolumn{6}{|c|}{ Parameters (as \% of dry matter) } & \multirow{2}{*}{$\begin{array}{c}\text { Gross } \\
\text { energy } \\
(\mathrm{KJ} / 100 \mathrm{~g})\end{array}$} & \multirow{2}{*}{$\begin{array}{l}\text { P/E ratio (g } \\
\text { Protein/KJ) }\end{array}$} \\
\hline & & & $\begin{array}{c}\text { Crude } \\
\text { protein }\end{array}$ & $\begin{array}{c}\text { Ether } \\
\text { extract }\end{array}$ & $\begin{array}{l}\text { Crude } \\
\text { fibre }\end{array}$ & Ash & NFE & $\begin{array}{c}\text { Total organic } \\
\text { matter }\end{array}$ & & \\
\hline $\mathrm{T}_{0}$ & 7.55 & 92.45 & 28.25 & 15.86 & 5.63 & 12.34 & 37.92 & 87.66 & 1702.96 & 60.28 \\
\hline $\mathrm{T}_{1}$ & 7.70 & 92.3 & 27.60 & 15.42 & 6.64 & 12.11 & 38.23 & 87.89 & 1680.70 & 60.89 \\
\hline $\mathbf{T}_{\mathbf{2}}$ & 9.15 & 90.85 & 27.82 & 14.98 & 7.27 & 11.28 & 38.65 & 88.72 & 1674.80 & 60.20 \\
\hline $\mathbf{T}_{3}$ & 9.55 & 90.45 & 27.25 & 14.48 & 6.39 & 10.25 & 41.63 & 89.75 & 1696.19 & 62.25 \\
\hline $\mathrm{T}_{4}$ & 8.17 & 91.83 & 27.23 & 14.20 & 7.07 & 9.20 & 42.30 & 90.8 & 1696.49 & 62.30 \\
\hline
\end{tabular}

Table.3 Proximate composition of experimental diets (on wet weight basis)

\begin{tabular}{|c|c|c|c|c|c|c|}
\hline $\begin{array}{c}\text { Experimental } \\
\text { Diet }\end{array}$ & Moisture & $\begin{array}{c}\text { Crude } \\
\text { protein }\end{array}$ & $\begin{array}{c}\text { Ether } \\
\text { extract }\end{array}$ & $\begin{array}{c}\text { Crude } \\
\text { fibre }\end{array}$ & Ash & NFE \\
\hline $\mathrm{T}_{0}$ & 7.55 & 26.12 & 14.66 & 5.20 & 11.39 & 35.06 \\
\hline $\mathrm{T}_{1}$ & 7.70 & 25.47 & 14.32 & 6.13 & 11.18 & 35.29 \\
\hline $\mathrm{T}_{2}$ & 9.15 & 25.27 & 13.61 & 6.60 & 10.25 & 35.11 \\
\hline $\mathrm{T}_{3}$ & 9.55 & 24.65 & 13.10 & 5.78 & 9.20 & 37.65 \\
\hline $\mathrm{T}_{4}$ & 8.17 & 25.01 & 13.04 & 6.49 & 8.45 & 38.84 \\
\hline
\end{tabular}

Table.4 Growth performance of the experimental animals

\begin{tabular}{|c|c|c|c|c|c|c|}
\hline Treatment & Replications & $\begin{array}{l}\text { Initial } \\
\text { weight } \\
\text { (g) }\end{array}$ & $\begin{array}{l}\text { Weight after } \\
30 \text { days (g) }\end{array}$ & $\begin{array}{l}\text { Weight } \\
\text { after } \mathbf{6 0} \\
\text { days (g) }\end{array}$ & $\begin{array}{l}\text { Weight after } \\
90 \text { days (g) }\end{array}$ & $\begin{array}{c}\text { Survival } \\
(\%)\end{array}$ \\
\hline \multirow[t]{2}{*}{$T_{0}$} & $\mathrm{~T}_{0} \mathrm{~A}$ & 3.61 & 7.50 & 11.59 & 15.11 & \multirow[t]{2}{*}{95.74} \\
\hline & $\mathrm{T}_{0} \mathrm{~B}$ & 3.60 & 7.47 & 11.62 & 14.90 & \\
\hline \multirow[t]{2}{*}{$\mathrm{T}_{1}$} & $\mathrm{~T}_{1} \mathrm{~A}$ & 3.60 & 7.46 & 11.60 & 15.31 & \multirow[t]{2}{*}{94.29} \\
\hline & $\mathrm{T}_{1} \mathrm{~B}$ & 3.59 & 6.89 & 10.69 & 14.99 & \\
\hline \multirow[t]{2}{*}{$\overline{T_{2}}$} & $\mathrm{~T}_{2} \mathrm{~A}$ & 3.58 & 7.40 & 11.64 & 15.88 & \multirow[t]{2}{*}{93.33} \\
\hline & $\mathrm{T}_{2} \mathrm{~B}$ & 3.61 & 8.45 & 13.80 & 18.31 & \\
\hline \multirow[t]{2}{*}{$\mathbf{T}_{3}$} & $\mathrm{~T}_{3} \mathrm{~A}$ & 3.62 & 8.47 & 13.71 & 18.02 & \multirow[t]{2}{*}{96.19} \\
\hline & $\mathrm{T}_{3} \mathrm{~B}$ & 3.58 & 7.84 & 12.35 & 17.38 & \\
\hline \multirow[t]{2}{*}{$\mathbf{T}_{4}$} & $\mathrm{~T}_{4} \mathrm{~A}$ & 3.59 & 5.44 & 8.55 & 12.29 & \multirow[t]{2}{*}{94.76} \\
\hline & $\mathrm{T}_{4} \mathrm{~B}$ & 3.62 & 6.46 & 9.58 & 13.22 & \\
\hline
\end{tabular}


Int.J.Curr.Microbiol.App.Sci (2018) 7(10): 2949-2961

Table.5 Parameters to analyze growth performance of experimental animals

\begin{tabular}{|c|c|c|c|c|c|c|c|c|c|c|c|c|c|c|c|}
\hline \multirow[t]{2}{*}{ Parameters } & \multicolumn{3}{|c|}{$\mathrm{T}_{0}$} & \multicolumn{3}{|c|}{$T_{1}$} & \multicolumn{3}{|c|}{$\mathbf{T}_{2}$} & \multicolumn{3}{|c|}{$\mathbf{T}_{3}$} & \multicolumn{3}{|c|}{$\mathrm{T}_{4}$} \\
\hline & $\mathbf{T}_{0} \mathbf{A}$ & $\mathbf{T}_{0} \mathbf{B}$ & Average & $\mathbf{T}_{1} \mathbf{A}$ & $\mathbf{T}_{1} \mathbf{B}$ & Average & $\mathbf{T}_{2} \mathbf{A}$ & $\mathbf{T}_{2} \mathbf{B}$ & Average & $\mathbf{T}_{3} \mathbf{A}$ & $\mathbf{T}_{3} \mathbf{B}$ & Average & $\mathbf{T}_{4} \mathbf{A}$ & $\mathbf{T}_{4} \mathbf{B}$ & Average \\
\hline $\begin{array}{c}\text { Initial } \\
\text { weight }(\mathrm{g})\end{array}$ & 3.61 & 3.60 & 3.61 & 3.60 & 3.59 & 3.60 & 3.58 & 3.61 & 3.6 & 3.62 & 3.58 & 3.6 & 3.59 & 3.62 & 3.61 \\
\hline $\begin{array}{c}\text { Final } \\
\text { weight }(\mathrm{g})\end{array}$ & 15.11 & 14.90 & 15.01 & 15.31 & 14.99 & 15.15 & 15.88 & 18.31 & 17.10 & 18.02 & 17.38 & 17.7 & 12.29 & 13.22 & 12.76 \\
\hline $\begin{array}{l}\text { Weight } \\
\text { gain }(\mathrm{g})\end{array}$ & 11.52 & 11.30 & $11.40^{b}$ & 11.70 & 11.40 & $11.55^{\mathrm{b}}$ & 12.30 & 14.70 & $13.5^{\mathrm{ab}}$ & 14.40 & 13.80 & $14.10^{\mathrm{a}}$ & 8.70 & 9.60 & $9.15^{\mathrm{c}}$ \\
\hline $\begin{array}{c}\text { Percentage } \\
\text { weight gain } \\
(\%)\end{array}$ & 318.56 & 313.89 & $316.23^{b}$ & 324.10 & 317.55 & $320.83^{b}$ & 343.58 & 407.20 & $374.9^{\mathbf{a b}}$ & 397.80 & 385.47 & $391.64^{\mathrm{a}}$ & 242.34 & 265.19 & $253.77^{\mathbf{c}}$ \\
\hline $\begin{array}{c}\text { Daily } \\
\text { weight gain } \\
\text { (g) }\end{array}$ & 0.128 & 0.126 & 0.127 & 0.13 & 0.127 & 0.129 & 0.137 & 0.163 & 0.15 & 0.16 & 0.153 & 0.157 & 0.097 & 0.107 & 0.102 \\
\hline SGR $(\%) *$ & 1.59 & 1.57 & $1.58^{\mathrm{b}}$ & 1.61 & 1.59 & $1.60^{\mathrm{b}}$ & 1.66 & 1.80 & $1.73^{\mathrm{a}}$ & 1.78 & 1.76 & $1.77^{\mathrm{a}}$ & 1.38 & 1.44 & $1.41^{\mathrm{c}}$ \\
\hline $\begin{array}{c}\text { Total feed } \\
\text { fed (g) }\end{array}$ & 21.62 & 21.69 & $21.66^{b}$ & 21.53 & 21.32 & $21.43^{b}$ & 22.39 & 25.87 & $24.13^{\mathrm{a}}$ & 24.77 & 24.43 & $24.6^{\mathrm{a}}$ & 19.31 & 20.83 & $20.07^{\mathrm{c}}$ \\
\hline FCR * & 1.88 & 1.92 & $1.9^{b}$ & 1.84 & 1.87 & $1.86^{b c}$ & 1.83 & 1.76 & $1.80^{\text {cd }}$ & 1.72 & 1.77 & $1.76^{d}$ & 2.22 & 2.17 & $2.20^{\mathrm{a}}$ \\
\hline FER * & 0.53 & 0.52 & 5.56 & 0.54 & 0.27 & 0.41 & 0.55 & 0.57 & 0.56 & 0.58 & 0.56 & 0.57 & 0.45 & 0.46 & 0.455 \\
\hline $\begin{array}{l}\text { Protein } \\
\text { Fed (g) }\end{array}$ & 6.11 & 6.13 & 6.12 & 5.94 & 5.88 & 5.91 & 6.23 & 7.20 & 6.7 & 6.75 & 6.66 & 6.71 & 5.26 & 5.67 & 5.47 \\
\hline PER * & 1.15 & 1.13 & $1.14^{b}$ & 1.17 & 1.14 & $1.155^{\mathrm{b}}$ & 1.23 & $1.47^{\mathrm{a}}$ & 1.35 & 1.44 & 1.38 & $1.41^{\mathrm{a}}$ & 0.87 & 0.96 & $0.92^{c}$ \\
\hline
\end{tabular}

* NB: SGR = Specific growth rate; FCR = Food conversion ratio; FER $=$ Food efficiency ratio; PER = Protein efficiency ratio. 


\section{Ammonia - N}

The ammonia - $\mathrm{N}$ content of all the experimental tanks were recorded and it was found to be $0.5 \pm 0.19$ and $0.2 \pm 0.17 \mathrm{ppm}$ before and after water exchange, respectively.

\section{Growth parameters}

The survibility (\%) of $P$. hypophthalmus fed with different experimental diets varied $\mathrm{y}$ between 93.33 to $96.19 \%$ (Table).

The weight gain was varied significantly among different treatments at the end of the experimental period and was among the treatments the weight gain was significantly higher in $\mathrm{T}_{3}$ thanin other treatments.

The weight gain percentage of the experimental animal's o vary significantly) among different treatment groups at the end of the experimental period. Among the treatments the weight gain in $\mathrm{T}_{4}$ was significantly higher than other treatments. Almost, similar trend was also in case of SGR. Highest SGR was recorded in T (1.77 $\%)$ and the lowest in $\mathrm{T}_{4}(1.41 \%)$.

The lowest percent FCR was recorded in $\mathrm{T}_{3}$ (1.76) and the highest was in $\mathrm{T}_{4}$ (2.20). The feed efficiency ratio (FER) values for different treatments varied y between 0.41 to 0.57 with non-significant differences. The average PER value varied significant from0.92 $\left(\mathrm{T}_{4}\right)$ to $1.41\left(\mathrm{~T}_{3}\right)$.

The study was introduced highlighting the importance of the research need on the topic and explaining the main objectives of the investigation. The information on the nutrient requirement of fish in general and that of protein in particular have been reviewed in detail. Besides, various efforts undertaken to find a suitable alternative to fish meal in general and study on fish silage in particular have also been reviewed. Five isonitrogenous experimental diets (viz., $\mathrm{T}_{0}, \mathrm{~T}_{1}, \mathrm{~T}_{2}, \mathrm{~T}_{3}$ and $\mathrm{T}_{4}$ ) with $35 \%$ crude protein level were formulated by replacing fish meal at $0 \%$, $25 \%, 50 \%, 75 \%$ and $100 \%$ by a blended protein source consisting of one third each of fish silage, groundnut oil cake (GNOC) and soya bean meal (SBM). Besides fish meal and blended protein source as above; GNOC, SBM and mustard oil cake (MOC) were the other protein source. Besides, DORB was added as source of carbohydrate, Vita-best as the source of lipid, corn flour as binder and vitamin mineral mixture for fortification of the feed. The feeds were fed to Thai-pangas (Pangasianodon hypophthalamus) fingerlings reared under laboratory condition at about $4.0 \%$ of their body weight per day for 90 days. Water quality parameters and proximate composition of experimental diets were analysed following standard protocol. The growth performance of the experimental diets was analysed taking standard parameters. The water quality parameters like $\mathrm{DO}, \mathrm{pH}$, temperature, total alkalinity and ammonia nitrogen of the experimental tanks remained within the ideal range for fish culture throughout the experimental period. The experimental diets $\left(\mathrm{T}_{0}, \mathrm{~T}_{1}, \mathrm{~T}_{2}, \mathrm{~T}_{3}\right.$ and $\mathrm{T}_{4}$ ) had an average crude protein percentage of ranging from $28.25 \%$ to $27.23 \%$, average ether extract ranging from $15.86 \%$ to $14.20 \%$, NFE content ranging from $37.92 \%$ to $42.30 \%$, crude fibre content ranging from $5.63 \%$ to $7.07 \%$ and total ash from $12.34 \%$ to $9.20 \%$.The gross energy $(\mathrm{KJ} / 100 \mathrm{~g})$ for the experimental diets $\left(\mathrm{T}_{0}, \mathrm{~T}_{1}, \mathrm{~T}_{2}, \mathrm{~T}_{3}\right.$ and $\mathrm{T}_{4}$ ) was estimated to be 1702.96, 2510.02, 2510.96, 2499.80 and 2506.24, respectively. Accordingly, the $\mathrm{P} / \mathrm{E}$ ratio of the experimental diets $\left(\mathrm{T}_{0}, \mathrm{~T}_{1}, \mathrm{~T}_{2}, \mathrm{~T}_{3}\right.$ and $\left.\mathrm{T}_{4}\right)$ was estimated to be 60.28, 90.94, 90.26, 91.74 and 92.04 respectively. The growth parameters like average weight gain (g), specific growth rate (SGR) (\%), food efficiency ratio (FER), food conversion ratio (FCR) and protein 
efficiency ratio (PER) were recorded treatment wise. The growth performance of Pangasianodon hypophthalmus after feeding with different experimental diets was significantly different. After 90 days of culture the average weight gain percentage were $316.23 \%, 320.83 \%, 374.91 \%, 391.64 \%$ and $253.77 \%$, respectively for $\mathrm{T}_{0}, \mathrm{~T}_{1}, \mathrm{~T}_{2}$, $\mathrm{T}_{3}$ and $\mathrm{T}_{4}$. The experimental diet $\mathrm{T}_{3}$ with $75 \%$ of the fish meal content replaced showed significantly $(\mathrm{p}<0.05)$ higher growth rate, even significantly better than reference diet $\mathrm{T}_{0}$ containing $100 \%$ fish meal and $0 \%$ blended protein source. On the other hand, experimental diet $\mathrm{T}_{4}$ containing $0 \%$ fish meal and $100 \%$ blended protein source showed significantly $(\mathrm{p}<0.05)$ lower growth rate. The food conversion ratio (FCR) of $1.9\left(\mathrm{~T}_{0}\right)$, $1.86\left(\mathrm{~T}_{1}\right), 1.80\left(\mathrm{~T}_{2}\right), 1.76\left(\mathrm{~T}_{3}\right)$ and 2.20 $\left(\mathrm{T}_{4}\right)$ were recorded, among which $\mathrm{T}_{3}$ was significantly $(\mathrm{p}<0.05)$ better. Similarly, the protein efficiency ratio (PER) of $1.14\left(\mathrm{~T}_{0}\right)$, $1.155\left(\mathrm{~T}_{1}\right), 1.35\left(\mathrm{~T}_{2}\right), 1.41\left(\mathrm{~T}_{3}\right)$ and 0.92 $\left(\mathrm{T}_{4}\right)$ was recorded, among which $\mathrm{T}_{3}$ was significantly $(p<0.05)$ better. Analysis of the various parameters shows that the silage based blended protein source can replace the fish meal upto $75 \%$ in the Thai pangus $(P$. hypophthalmus) feed. After considering all the factors analysed in the study it may be concluded that the cost effective diet for $P$. hypophthalmus may be formulated like $\mathrm{T}_{3}$, replacing $75 \%$ of the fish meal with blended protein source for better performance in terms of growth of the fish.

\section{References}

Ali, S., Rahman, A. K., Patwary, A. R. and Islam, K. H. R. 1982. Studies the Diurnal variation in Physicochemical factors and zooplankton in a freshwater pond. Bangladesh J. Fish., 2(5); 15-23.

AOAC 1998. Official Methods of Analysis of the Association of Official Analytical Chemists, $16^{\text {th }}$ edition. AOAC
International, Gaithersburg, Maryland, 20877-2417, Vol. 1, Chapter 4:1-43 pp.

APHA. 1992. Standard Methods for the examination of water and Wastewater, $17^{\text {th }}$ edn. American Public Health Association, Washington, DC, 100-208 pp.

Ayyappan, S; Moza, U; Gopalkrishnan A; Meenakumari B; Jena, J. K. and Pandey A K., 2011. Handbook of Fisheries and Aquaculture $2^{\text {nd }}$ edn. Indian Council of Agricultural Research, New Delhi.

Borghesi, R. (2004). Avaliação físico-química e biológica das silagens ácida, biológica E enzimática elaboradas com descarte $\mathrm{e}$ resíduo do beneficiamento da tilápia do nilo (Oreochromis niloticus). Dissertação (Mestrado) - Escola Superior de Agricultura "Luiz de Queiroz", Universidade de São Paulo, Piracicaba, Brasil. 108p.

Bromely, P. J., 1980 Effect of dietary protein, lipid and energy content on the growth of turbot (Scopthalmus maximus). Aquaculture 19: 359-369.

Chamberlain, G. W. 2000. Aquaculture Projections for Use of Fishmeal and Oil. Oral representation at the Annual Meeting of IFOMA, Lima, Peru, 30 October-3 November, 2000.

Coello, M.M., Sanchez, M., Vicario, I.M., Heredia, F.J. \& Martin, M. (1999) Assessing acceptability of ell (Anguilla anguilla) fed three different diets. J.Sci. Food Agric., 79, 2087-2093.

Cowey, C.B. and J.R. Sargent., 1979. Nutrition in fish physiology, Vol.8. W.S., D.J. Randall and J.R. Brett, eds. Academic Press, New York, pp. 1-69.

Crampton, V.; Bromage, N. and Watret, R., 1982. Moist feed for salmon. Fish Farm., 5:11.

Cremer, M. Zhan J. and Zhou, E. 2002. Pacu (Piaractus brachypomus) production in pond with soy-based feed. www.fishbase.org. 
Espe, M.; Haaland, H.; Njaa, L. R. 1992. Autolysed fish silage a feed ingredient for Atlantic Salmon (Salmo salar). Composition Biochemistry Physiology, 103, 369-372.

Fagbenro, O., Januncey, K.; Haylor, G. 1994. Nutritive value of diets containing dried lactic acid fermented fish silage and soyabean meal for gariepinus. Aquatic Living Resource, 7, 79-85

Fagbenro, O.; Jauncey, K. 1998. Physical and nutritional properties of moist fermented fish silage pellets as a protein supplement for tilapia (Oreochromis niloticus). Animal feed Science and Technology, 71, 11-18

FAO, 2015. Aquaculture feed and fertilizer resources information system of FAO. Stripped catfish- Nutritional requirements.

http://www.fao.org/fishery/nems/40381/ en

FAO. 2003. Animal feed resources information system. http://www.fao.org. (23 Jan. 2003).

Ferraz de Arruda, L. 2004. Aproveitamento do residuo do beneficiamento da tilapia do nilo (Oreochromis niloticus) para obtencao de silagem e oleo como subprodutos. Dissertacao (mestrado) Escola Superior De Agricultura "Luiz De Queiroz", Universidade De Sao Paulo, Piracicaba, Brasil. 78p.

Giri, S.S. 2013, Recent trends in Aquatic Nutrition and food-feed scenario. In: compendium of lectures of winter school on sustainable fish feeds and nutraceuticals to grow health promoting fish. Held at CIFA, Bhubaneswar, Odisha on 15 Jan-7Feb 2013. 11-18pp.

Goddard, J.S., Perret, J.S.M. 2005. Co-drying fish silage for use in aquafeeds. Animal Feed Science and Technology, 118, 337-342.

Gonclaves, J.F., Santos, S., Pereira, V.S., Baptista, I. and Coimbra, J., 1989. The use of fish silage as an ingredient for eel fingerling nutrition. Aquaculture, 80: $135-146$.

Gullu, K., Acar, U., Tezel, R. and Yozukmaz, (2014) Replacement of fish meal with fish processing by-product silage in diets for the rainbow trout, Oncorhynchus mykiss. Pakistan, J. Zool., Vol. 46 (6), pp. 1697-1703.

Guroy, B., Sahin, I., Kayali, S. Mantoglu, S., Canan, B. Merrifield, D.L., Davies, S.J. \& Guroy, D. (2013) Evaluation of feed utilization and growth performance of juvenile striped catfish Pangasianodon hypophthalmus fed diets with varying inclusion levels of corn gluten meal. Dept. of Aquacult. Armutlu Vocational College, University of Yalova, Yalova, Turkey; Aquacult. and fish Nutr. Research Group, School of Biochemical and Biological Sciences, The University of Plymouth, Plymouth, Devon, UK., 19: 258-266

Heras, H.; Mcleod, C.A.; Ackman, R.G. 1994. Atlantic dogfish silage vs. herring silage in diets for atlantic salmon (Salmo salar): growth and sensory evaluation of fillets. Aquaculture, 125, 93-103.

Hillestad, M., Johnsen, F., 1994. Highenergy/ low-protein diets for Atlantic salmon: effects on growth, nutrient retention and slaughter quality. Aquaculture 124: 109- 116.

Honczaryk, A.; Maeda, L.S. 1998. Crescimento do pirarucu, Arapaima gigas, utilizando dieta à base de ensilado biológico de pescado. In: Simpósio Brasileiro de Aqüicultura, 10, Anais. Recife: Persona, 2, 93-100.

Hussain, R.A.K.; Offer, N. W. 1987. Effect of folmaldehyde treatment on the degradation of acid- preserved fish silage protein in vitro. Animal Feed Science and Technology, 16, 297-304.

Islam, S. Md. \& Tanaka, M., 2004. Optimization of dietary protein 
requirement for pond-reared masher, Tor putitora Hamilton (Cypriniformes: Cyprinidae). Aqucult. Res., 35, 12701276.

Jhingran, V. G., 1991. Fish culture in fresh water pond. In: fish and fisheries of India (ed. Jhingran, V. G.). III edn. Hindustan Publishing Corporation, New Delhi, pp. 276.

Josupeit, H. (2009b) Pangasius Market report - February 2009. FAO/ Globefish 2009.

Kathane, Y.M. (2013) Evaluation of protein sparing effect of carbohydrate in fringelipped carp (Labeo fimbriatus).

Kompiang, I. P. 1981. Fish silage: its prospect and future in Indonesia. Indonesia Agricultura Research and Development Journal, 3, 9-12.

Lessi, E; Ximenes Carneiro, A. R.; Lupin, H. M. 1989. Obtención de ensilado biológico. In: Consulta de Expertos sobre Tecnologia de Productos Pesqueros en America Latina, 2, Montevideo, Anais. Roma: FAO, 8p.

Mohanty, S.N. 2013. Present Status and future Strategies in Fish Nutrition: Regional Aqua feed and Category IN: compendium of lectures of winter school on sustainable fish feeds and nutraceuticals to grow health promoting fish. Held at CIFA, Bhubaneswar, Odisha in 15 Jan- 7 Feb 2013. 19- 31 pp.

Nabil, F. Abd El-Hakim; Mahmoud O.A. ElGendy; Mahmoud F.I. Salem. (2007) Effect of incorporation of fish silage into diets on growth performance and body composition of Nile tilapia (Oreochromis niloticus). Egypt. J. Aquat. Biol. \& Fish., Vol. 11, No. 2: 101-117.

Nambudiri, D.D., (1985) Analytical Manual of fish and fishery products. Kerala Agricultural University.

New, M. B. \& Wijkstom, U. N. 2002. Use of Fishmeal and Fish Oil in Aquafeeds:
Further Thoughts on the Fishmeal trap. FAO Fisheries Circular No. 975 F1PP/C975. Food and Agriculture Organization of the United Nation, Rome.

Phuong, N.T., Liem, P.T. \& Tuan, N.A. (2005) An overview of catfish farming industry in the Mekong river delta of Vietnam (Abstact). Proceedings of World Aquaculture Society, 9-13 May 2005, Bali, Indonesia, $621 \mathrm{pp}$.

Ristic, M.D. Filipovic, S.S.; Sakac, M.L.J. (2002) Liquid protein feedstuffs from freshwater fish byproducts as a component of animal feed. Romanian biotechnological Letters, 7, 729-736

Salah Al-Din, S.A. (1995): Studies on unconventional rations in feeding of Nile catfish (Clarius Lazera). M.Sc. Thesis. Fac. Agric., Al-Azhar University.

Shah, S.A.; Malik, A.; Kalhoro, H.; Kalhoro, I.B.; Wadhar, G.M.; Maher, G.M. (2014) Growth performance of exotic catfish Pangas, Pangasianodon hypophthalmus (Sauvage, 1878) at Fish Hatchery Chilya Thatta, Sindh, Pakistan, Sindh Univ. Res. Jour. (Sci. Ser.) Vol.46 (2): 205-208.

Sheen, S.S. Chen, C.T. and Ridwanudin, A. (2014). The effect of partial replacement of fish meal protein by dietary hydrolyzed fish protein concentrate on the growth performance of Orange-spotted grouper, Epinephalus coioides. Journal of aquaculture \& Marine Biology. Vol. 1 issue 2.

Soltan, M.A. and Samra, I.M. (2010). Partial or complete replacement of fish meal by fermented fish by-products silage in the diets of Nile tilapia (Oreochromis niloticus) fingerlings. Abbassa Int. J. Aqua. Special issue. The third scientific Conference, Al azhar University, Cairo17-18 October 2010 
Steffens, W. (1987) Use of poultry byproducts for complete replacement of fish meal in feeds for trout fry and fingerlings. Arch. Tierernaehr., 37, 98103.

Stone, F.E., Hardy, R.W., Shearer, K.D. and Scott, t.m., 1989. Utilization of fish silage by rainbow trout (Salmo gairdneri). Aquaculture, 76:109-118.

Tacon, A.G.J. \& Metian, M. (2008) Global overview on the use of fish meal and fish oil in industrially compounded aquafeeds. Trends and future prospects. Aquaculture, 285, 146-158.

Tatterson, J. N.; Windsor, M. L. (1974), Fish silage. Journal of Science Food and Agriculture, 25, 369- 379.

Vergara, J.M., Lopez-Calero, G., Robina, L., Caballero, M.J., Montero, D., Izueierdo,
M.S., Asksnes, A., 1999. Growth, feed utilization and body lipid content of gilthead seabream (Sparus aurata) fed increasing lipid levels and fish meal of different quality. Aquacult. 179: 35-44.

Viana, M. T.; Guzman, J.M.; Escobar, R. (1999), Effect of heated and unheated fish silage as a protein source in diets for abalone Haliotis fulgens. Journal of The World Aquaculture Society, 30, 481-489.

Vidotti, R.M.; Viegas, E.M.M.; Carneiro, D.J. (2003), Amino acid composition of processed fish silage using diferent raw materials. Animal Feed Science and Technology, 105, 199-204.

Wantanabe, C. D., 1982. Lipid nutrition in fish Comp. Biochem. Phy-siol73B:3- 15

\section{How to cite this article:}

Makamguang Kamei, Brundaban Sahu, Sudhanshu Raman, Soumendra Nanda, Dhariti Choudhury and Dorothy, M.S. 2018. Use of Fish Silage Based Blended Protein Source for Replacement of Fish Meal in Thai-Pangas Diet. Int.J.Curr.Microbiol.App.Sci. 7(10): 29492961. doi: https://doi.org/10.20546/ijcmas.2018.710.342 